\title{
Users' Experience towards the Use of Mobile Applications
}

\author{
R. Uma
}

\begin{abstract}
In this digital era, with day to day inventions and innovations, business and service firms are struggling hard to remain successful. Today, more and more interactions occurs online through mobile devices.Mobile applications (apps) have become a popular tool for business marketing and customer engagement. There is a persistent need for all business and e-commerce ventures to be mobile-friendly.The main aim of this paper is to have a clear understanding about the mobile users experience with the various mobile applications (apps) which they use frequently. The questionnaire method has been applied to collect data from 60 respondents. The findings of the study would help to provide strategies for marketers which can be adopted for creating a superior customer experience.
\end{abstract}

Keywords : Mobile apps, usage pattern, users experience and satisfaction.

\section{INTRODUCTION}

M obile Commerce (M-Commerce) -is a new emergence of E-Commerce. With active engagement of customers using mobile devices, every business is using mobile applications (apps)- a technological advancement, as a valuable tool, to connect and interact with them. Today, all businesses have a mobile app, just like they have a website, as these mobile apps play a dominant role in the digital world. With the rise of the new digital customers and their increasing expectations, every business must try to provide a mobile-friendly experience to their users. The primary purpose of this paper is to understand the experience of mobile application (app) users based on Strategic Experiential Model (SEM) given by Schmitt (1999); to analyze the satisfaction of the users' with the mobile applications; and suggest measures to enhance users' experience while using the various mobile applications to marketers.

\section{A. Objectives}

1. To identify the personal profile of mobile users in Chennai city;

2. To understand the users' experience towards the use of various mobile applications; and

3. To analyze the users' level of satisfaction with mobile applications (apps) and suggest measures to improve it.

Revised Manuscript Received on December 05, 2019.

* Correspondence Author

Dr. R. UMA*, Associate Professor, Department of Commerce, Anna Adarsh College For Women, Chennai, India. E Mail ID ramaumamohan@gmail.com

\section{BACKGROUND OF THE RESEARCH / LITERATURE REVIEW}

Beniwal and Sharma (2013) study stated that youth are more dependent on mobile phones and its dependency is increasing to a greater extent.According to Johnson(2015) study, a good experience of mobile app user helps to promote sales of mobile apps as well as help in spreading a positive word of mouth communication.Cerejo (2012) study has evaluated that users choice to select mobile apps to a greater extent is influenced by its content.Albert \&Tullis (2013) described that design of app must be based on users interest and requirements. According to Schmitt (1999), based on strategic experience model (SEM), experience has been classified asSense experience is an experience which a customer gains from his own senses;Feel experience refers to developing a good rapport between customer and the marketer;Think experience refers to a favourableattitude towards the products/services of the company; Act experience is an experience that influences customer's physical appearance, lifestyle and behavior developed from their social interaction with other people and; Relate experience refers to the experiences which the customers gainthrough company's propaganda plans and connect themselves to society.

\section{JUSTIFICATION OF THIS PAPER}

The literature review identified many factors and these have been included such as the brand of mobile device used, various mobile apps used, time spent by users, frequency of use, the experience of the users with mobile apps relating tosense, feel, think, act and relate based on Strategic Experiential Model (SEM) given by Schmitt (1999); and their level of satisfaction towards mobile applications (apps). The study identified that understanding the experience of the users using SEM is missing. This study provides insights in these related issues. Additionally, the current research also provides managerial implications to optimize users experience with the mobile applications (apps).

\section{RESEARCH DESIGN}

This study uses both primary and secondary data.The primary data is collected from 60 respondents, to know about their experiences toward usage of mobile apps through a well structured questionnaire. 


\section{Users' Experience Towards the Use of Mobile Applications}

A convenience sampling technique is applied. The respondents from Chennai city have been selected on the basis of convenience. Secondary data is collected from books, journals, periodicals and website. The simple percentage method has been applied for this paper.

\section{ANALYSIS OF DATA AND INTERPRETATION}

\section{Demographic Profile and Usage Pattern of Respondents}

Table 1.1: Demographic Profile of Respondents and Mobile Application (app) Usage Pattern of Respondents

\begin{tabular}{|c|c|c|}
\hline & Frequency & Percent \\
\hline \multicolumn{3}{|l|}{ Age } \\
\hline $\begin{array}{l}\text { Below } 18 \text { years } \\
\text { 18-25years } \\
\text { 26-35years } \\
\text { 36-45years } \\
\text { 46-55years } \\
\text { Above 55years }\end{array}$ & $\begin{array}{c}5 \\
7 \\
10 \\
15 \\
13 \\
10\end{array}$ & $\begin{array}{c}8.33 \\
11.69 \\
16.66 \\
25.00 \\
21.66 \\
16.66\end{array}$ \\
\hline \multicolumn{3}{|l|}{ Gender } \\
\hline $\begin{array}{l}\text { Male } \\
\text { Female }\end{array}$ & $\begin{array}{l}33 \\
27\end{array}$ & $\begin{array}{l}55 \\
45\end{array}$ \\
\hline \multicolumn{3}{|l|}{ Education } \\
\hline $\begin{array}{l}10 /+2 \\
\text { UG } \\
\text { PG } \\
\text { Professional } \\
\text { Diploma Holder }\end{array}$ & $\begin{array}{c}6 \\
26 \\
13 \\
12 \\
3\end{array}$ & $\begin{array}{c}10.00 \\
43.4 \\
21.6 \\
20.00 \\
5.00\end{array}$ \\
\hline \multicolumn{3}{|l|}{ Occupation } \\
\hline $\begin{array}{l}\text { Salaried Employee } \\
\text { Business/Self- Employed } \\
\text { House-Wife } \\
\text { Student } \\
\text { Retired }\end{array}$ & $\begin{array}{c}18 \\
13 \\
15 \\
12 \\
2 \\
\end{array}$ & $\begin{array}{c}30.00 \\
21.66 \\
25.00 \\
20.00 \\
3.34 \\
\end{array}$ \\
\hline \multicolumn{3}{|l|}{ Monthly/family income } \\
\hline $\begin{array}{l}\text { Below Rs. } 10,000 \\
\text { Rs. } 10000-\text { Rs. } 20000 \\
\text { Rs. } 20001-\text { Rs. } 30000 \\
\text { Rs.30001-Rs. } 40000 \\
\text { Rs.40000-Rs. } 50000 \\
\text { Above Rs.50000 } \\
\end{array}$ & $\begin{array}{c}5 \\
6 \\
10 \\
16 \\
6 \\
17 \\
\end{array}$ & $\begin{array}{l}8.33 \\
10.00 \\
16.67 \\
27.00 \\
10.00 \\
28.00 \\
\end{array}$ \\
\hline \multicolumn{3}{|l|}{ Brand Name } \\
\hline $\begin{array}{l}\text { Apple I Phone } \\
\text { LG } \\
\text { Samsung } \\
\text { Sony } \\
\text { Windows Phone - Nokia Lumia } \\
\text { Others }\end{array}$ & $\begin{array}{c}7 \\
9 \\
13 \\
10 \\
9 \\
12 \\
\end{array}$ & $\begin{array}{c}11.7 \\
15.0 \\
21.3 \\
1.0 \\
15.0 \\
20.0 \\
\end{array}$ \\
\hline \multicolumn{3}{|l|}{ Frequency of use } \\
\hline $\begin{array}{l}\text { Daily } \\
\text { Once in a week } \\
\text { Once in 15days } \\
\text { Once in a month } \\
3 \text { months } \\
6 \text { months }\end{array}$ & $\begin{array}{c}18 \\
12 \\
7 \\
14 \\
7 \\
2 \\
\end{array}$ & $\begin{array}{r}30.00 \\
20.00 \\
11.66 \\
23.34 \\
11.66 \\
3.34 \\
\end{array}$ \\
\hline \multicolumn{3}{|l|}{ Time spent } \\
\hline $\begin{array}{l}\text { Less than } 1 \mathrm{Hr} \text {. } \\
\text { Between 1-3 Hrs. } \\
\text { More than } 3 \mathrm{Hrs} \text {. }\end{array}$ & $\begin{array}{l}18 \\
22 \\
20\end{array}$ & $\begin{array}{l}30.00 \\
36.60 \\
33.40\end{array}$ \\
\hline
\end{tabular}

Respondents

\begin{tabular}{|c|c|c|}
\hline TYPES & Frequency & Percent \\
\hline Online banking app & 11 & 18.34 \\
Social media app & 14 & 23.33 \\
E wallet app & 10 & 16.66 \\
Food delivery app & 5 & 8.34 \\
Online shopping app & 9 & 15.00 \\
E-ticketing app & 7 & 11.67 \\
Others & 4 & 6.66 \\
\hline Total & 60 & 100.00 \\
\hline
\end{tabular}

Interpretation: Table1.2, shows that $23.33 \%$ of the respondents use social media app frequently, while $18.34 \%$ use online banking app, $16.66 \%$ use e-wallet app, 15\% use online shopping app, $11.67 \%$ use e-ticketing app, $8.34 \%$ use food delivery and $6.66 \%$ use other apps such as entertainment app, e-learning and health care apps.

\section{Users' Experience Towards Various Mobile Application}

Table 1.3: Users' Experience Towards Various Mobile Application

\begin{tabular}{|c|c|c|}
\hline USERS Experience & Frequency & Percent \\
\hline $\begin{array}{c}\text { Sense experience (visual appearance of mobile } \\
\text { apps) }\end{array}$ & 14 & 23.33 \\
Feel experience (user-friendly) & 23 & 38.33 \\
Think experience (provides relevant \\
$\begin{array}{c}\text { information) } \\
\text { Act experience (allows to share information) }\end{array}$ & 10 & 16.67 \\
Relate experience (creates a sense of trust) & 7 & 11.67 \\
\hline TOTAL & 60 & 10.00 \\
\hline
\end{tabular}

Interpretation: Table 1.3 reveals the experience of users during their usage of mobile applications (apps). $23.33 \%$ of the respondents have stated that mobile apps are visually appealing, 38.33\% feel that it is user-friendly, while $16.67 \%$ think that it provides necessary content, $11.67 \%$ have stated that mobile apps allows the users to share information to others and $10 \%$ have stated that it creates a sense of trust while using the mobile applications.

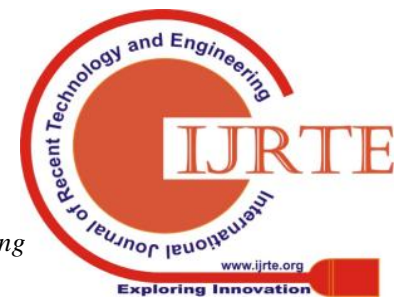




\section{Overall Satisfaction of Respondents with Mobile App}

Table 1.4: Overall Satisfaction of Respondents with Mobile App

\begin{tabular}{|c|c|c|}
\hline Overall Satisfaction & Frequency & Percent \\
\hline Highly satisfied & 12 & 20.00 \\
Satisfied & 27 & 45.00 \\
No idea & 6 & 10.00 \\
Dissatisfied & 8 & 13.33 \\
Highly dissatisfied & 7 & 11.67 \\
\hline TOTAL & 60 & 100.00 \\
\hline
\end{tabular}

Interpretation: Table 1.4 reveals that $20 \%$ of mobile application users have high level of satisfaction with the use of mobile apps, $45 \%$ are satisfied and $10 \%$ have no idea, while $13.33 \%$ are dissatisfied and $11.67 \%$ are highly dissatisfied with their mobile applications (apps)

\section{Patronage Intentions of Respondents}

Table 1.5: Patronage Intentions of Respondents

\begin{tabular}{|c|c|c|}
\hline Patronage Intentions & Frequency & Percent \\
\hline Yes & 32 & 53.33 \\
No & 21 & 35.00 \\
Don't know & 7 & 11.67 \\
\hline TOTAL & 60 & 100.00 \\
\hline
\end{tabular}

Interpretation: Table 1.5 reveals that $53.33 \%$ of the respondents have intentions to patronize the mobile apps what they are using, while $35 \%$ have no such intentions and $11.67 \%$ have no idea about it.

\section{MANAGERIAL IMPLICATIONS}

To optimize users experience with the mobile applications (apps) the following strategies can be applied.

\section{A. Visual Appeal}

The design of mobile applications(apps) must look attractive to draw users' senses. This powerful non-verbal communication method can include features such as use of attractive colors, a good typography, appealing graphic design, use of visual elements of the apps such as icon/ logo and use of correct font size to target the mobile application users.

\section{B. Customer-Centric}

Mobile applications (apps) should be simple, clear and easy-to-navigate, work errorless and also be compactable and suitable for users of different mobile devices. An off-line mode can also be created for the users.

\section{Quality and Performance}

A well-designed application (app) should provide for customized content, present instant information and up-to-date content for its users, also help to find products/services they need effortlessly and also provide for quick responses to users inquiries in order to provide a great experience for the users of mobile application.

\section{Sharing of information}

The users of mobile application (app) must be given an opportunity to rate the app and offer their reviews both positive /negative in order to help the developers of app to correct the shortcomings of the app and make it more meaningful to the users.

\section{E. Security/Privacy Issues}

A mobile application (app) should provide appropriate features for maintaining users personal information, credit card information that could be shared in an app more confidential while doing on-line transactions as it increases the trust worthiness of users on mobile apps.

\section{CONCLUSION}

Understanding users experience with mobile apps has become imperative in today's digital world. The study has been conducted with this objective by using questionnaire method and data has been collected from 60 respondents. The study revealed that majority of the respondents frequently use social media application (app), followed by banking and other related apps. The findings of the study indicated that M-designers should take necessary steps to create and develop well-designed mobile apps in order to provide a superior quality and performance to its users. Constant efforts also should be taken to amend and update the functions to enhance users experience and gain a competitive advantage successfully.

\section{REFERENCES}

1. Albert, W. and Tullis, T. (2013). Measuring the user experience: collecting, analyzing, and presenting usability metrics, Newness.

2. Beniwal ,K.and Sharma, A. (2013). Explosive growth of Mobile Technology and its Potential Impact on Youth \& Education.

3. Cerejo, L. (2012). The Element of Mobile User experience.

4. Johnson, K. (2015). The Importance of User Experience for Mobile Apps

5. Schmitt, B. (1999). Experiential Marketing, Journal of Marketing Management, 15 (1-3)

\section{AUTHOR PROFILE}

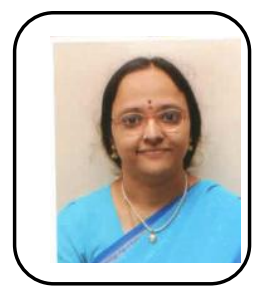

Dr. R.UMA is working as Associate Professor, PG and Research Department of Commerce, Anna Adarsh College for Women, Anna Nagar, Chennai. Has 28 years of teaching experience at UG level and 27 years at the PG level till date. Completed Master's Degree and M.Phil., Degree in Commerce from University of Madras. Holds Doctorate Degree from Department of Management Studies, University of Madras. A Research Guide and Supervisor for M.Phil., (Full-Time) in Commerce and Ph.D., (Part-time) in Commerce. The area of specialization is Marketing and HR. Has participated and presented papers at various State, National and International Seminar/Conference/Workshop/Symposium. Published research articles at National and International journals with a high impact factor.Has been a Member of Inspection Commission, a Member of Audit Panel for Academic Audit and has also been appointed as an External Examiner for conducting Public Viva-voce Examination of research candidate for the award of Ph.D., Degree of Bharathiar University, Coimbatore. 